\title{
Bligh Grant
}

Centre for Local Government

University of Technology Sydney

\section{Perspectives on Australian Local Government Reform edited by Brian Dollery and lan Tiley}

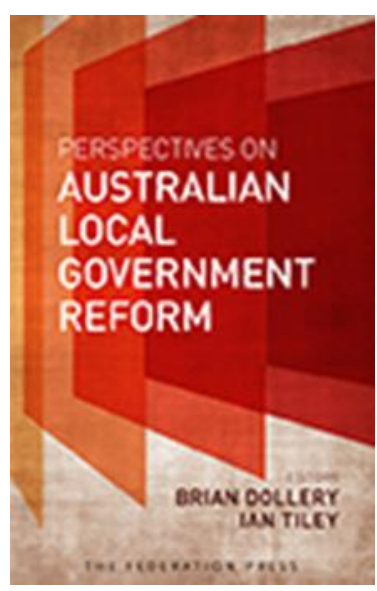

(The Federation Press $1+191 p p$; RRP: \$49.95)

www.federationpress.com.au/bookstore/book.asp?isbn=9781862879

850

Academic books emerge in a variety of ways. Some are the result of pure serendipity. For instance, in February 2011 Brian Dollery and I were completing a report that delved into the conceptual and theoretical foundations of shared services. Brian had also co-authored several case studies of shared services in Australian local government over the years, some of which I had contributed to.

One morning while he was in my office I suggested to Brian that these two elements - the theory of shared services on the one hand and the lived experience on the other - could be brought together to form a volume on the topic, as opposed to the information being scattered throughout academic journals that relatively few people had access to. Brian ignored the comment at the time, but several mornings later came back in to see me at my desk. Bending down quite close to me he said: "You know that idea you had about a book on shared services ... that's a very good idea... In fact, it's such a good idea I'm surprised I didn't think of it myself..." The rest, as they say is history - and no, it's not a particularly inspiring volume, but Councils in Cooperation: Shared Services and Australian Local Government (Dollery et al. 2012) by Brian, myself and our colleague Michael Kortt at Southern Cross University is a tidy little book which may - or may not - have had some influence on reform processes in Australian local government (witness, for example, the emphasis on joint organisations in the 'Final Report' of the NSW Government's Independent Local Government Review Panel's (2013) Revitalising Local Government.

(C) 2015 Bligh Grant. This is an Open Access article distributed under the terms of the Creative Commons Attribution 4.0 Unported (CC BY 4.0) License (https://creativecommons.org/licenses/by/4.0/), allowing third parties to copy and redistribute the material in any medium or format and to remix, transform, and build upon the material for any purpose, even commercially, provided the original work is properly cited and states its license.

Citation: Commonwealth Journal of Local Governance 2015, 18: 4851, - http://dx.doi.org/10.5130/cjlg.v0i18.4851 
Alternatively, some books - particularly edited ones (edited special editions of journals are the same) - can be organised with a military precision, involving not only rigorous project management but also a detailed structuring of the contents. Witness, for example, the collection Local Government Reform: A Comparative Analysis of Advanced Anglosphere Countries edited by Dollery, Garcea and LeSage and published by Edward Elgar in 2008. In this book the categories of structural, functional, financial, organisational and jurisdictional reform are used to analyse reform processes generally for local government systems in a variety of countries.

The most recent volume from our colleagues in Armidale is Perspectives on Australian Local Government Reform, edited by Brian Dollery and Ian Tiley, published by Federation Press. The motivation and execution of this book feels like neither of the two types described above. Rather, it is suggests that: 'A lot has been going on in the local government systems of Australia recently - we should do an edited book'. The result of this more liberal approach is a trove of insights into contemporary local government reform across Australia's federal system of government, written by people who have been critically positioned within these diverse reform processes, alongside reflections by leading academics in the field.

Of the 11 substantive chapters, four are concerned with NSW. Ian Tiley pens a case study of the Clarence Valley Council, addressing the question of whether or not Clarence Valley constitutes an example of a successful merger. Financial reforms to local government are the focus of the contribution by John Truman of Ballina Council. Drawing on his extensive experience, Brian Bell examines a particular form of inter-regional collaboration, councils of mayors, against the backdrop of the current reforms in NSW. And, of burning interest to anyone involved in current NSW events, an account of these processes is provided by the former Minister for Local Government Don Page - one of the most humble and diligent Australian politicians I have had the privilege to meet.

However, arguably it is the chapters examining the less frequently reflected upon jurisdictions that are of particular interest, principally for reasons of comparison into on-going reform in other jurisdictions. For instance, in their contribution examining the issue of structural reform in Tasmania, Ron Sanderson, General Manager of Brighton Council (interviewed in 2011 in Dollery and Grant 2011), and long-standing servant of Tasmanian local government Stewart Wardlaw, document, amongst other issues, how three councils in that state successfully challenged in the Supreme Court of Tasmania a recommendation by the (then) Local Government Board to reduce the number of councils from 29 to 14, and how the incumbent Liberal government was subsequently defeated in the ensuing state election. 
In his contribution examining South Australian local government, CEO of Port Pirie Regional Council Andrew Johnson documents, amongst other issues, the comparative paucity of per capita funding for local government areas in that state. Stephen Goode juxtaposes the non-amalgamation of Perth councils with the extended processes of self-examination undertaken by the West Australian local government sector since 2006. And Michael Kortt and Joe Wallis reflect upon the strategic effects of the radical amalgamation programme undertaken in Victoria in 1993.

Two contributions adopt distinctive and refreshing methodological approaches to their subject matter. In her examination of recent amalgamation and de-amalgamation in Queensland, Gabrielle Walsh argues that the concept of 'the local state', rather than local government conceived principally as an administrative arm of state government, allows an appreciation of state-local relations. Adopting this approach, Walsh takes into consideration the history of economic regionalism as an element of the political conflicts concerning the recent local government amalgamations and de-amalgamations in Queensland, and as such extends the dominant institutional sociology approach to local government studies in the Australian context.

Similarly, Thomas Michel deploys both his experience in the Northern Territory's local government sector and significant scholarly work to provide an account of the regionalisation of 53 community councils into just eight shire councils. Michel's approach is at once both critical and actuarial, as well as resting on a considerable body of ethnographic work, the latter inclusive of interviews of 831 residents in the Victoria Daly and Roper Gulf Shires and 77 residents of Central Desert and MacDonnell Shires. His conclusions include the observation that administrative reform, in particular structural reform, functions at least in part to allow "difficult questions about the past and present shortcomings of modern government's role in the Indigenous domain [to be] effectively ignored".

The final chapter by Chris Aulich canvasses the issue of options for recognition of local government by the Commonwealth - 'symbolic', 'institutional' and 'financial' types. The chapter is full of insights as to the 'awkward situation' of local governments in Australia. For instance, Aulich notes that despite its persistent refrain to be the tier of government that is closest to the people, empirical work - such as that conducted by AJ Brown - has correlated greater place attachment on the part of citizens' with less support for local government. Indeed, some of the results from the UTS: CLG's 'Why Local Government Matters' survey reflect this observation. Aulich also broaches the delicate issue of national leadership for Australian local government.

Taken as a whole, Perspectives on Australian Local Government Reform provides a valuable update on continuing processes of reform across Australian local government systems. The overall narrative is still one told through the lens of structural reform, or responses to the possibility of structural 
reform. However, there is plenty of other detail in the book. Both academics and practitioners will find it of interest for precisely this reason and the editors have assembled an enviable group of people to make the contributions.

\section{References}

Dollery, B., Garcea, J. and LeSage, E.C. (eds) (2008) Local government reform: A comparative analysis of advanced Anglo-American countries. Cheltenham: Edward Elgar.

Dollery, B. and Grant, B. (2011) Innovation in Tasmania: A conversation with Ron Sanderson, General Manager of Brighton Council. Local Government Voices Series 02-2011. Available at: www.une.edu.au/_data/assets/pdf_file/0019/16750/voices-02-ron-sanderson.pdf

Dollery, B., Grant, B. and Kortt, B. (2012) Councils in cooperation: Shared services and Australian local government. Annandale, Australia: Federation Press.

Independent Local Government Review Panel. (2013) Revitalising local government. Final Report of the NSW Independent Local Government Review Panel. Available at:

www.localgovernmentreview.nsw.gov.au/Information.asp?areaindex=LGR\&index=102\&mi=9 